\title{
COMPOSITE ZONES PRODUCED IN IRON CASTINGS BY IN-SITU SYNTHESIS OF TiC CARBIDES
}

\author{
STREFY KOMPOZYTOWE OTRZYMYWANE W ODLEWACH Z ŻELIWA W WYNIKU SYNTEZY IN SITU WĘGLIKÓW TiC
}

\begin{abstract}
The study discusses a method of producing composite zones at the edge of castings made of ferritic-pearlitic ductile iron. Composite zones were produced in castings made of ferritic-pearlitic ductile iron at the casting edge. The reinforcing phase for the composite zone was TiC carbide, obtained by in-situ synthesis of substrates introduced into the mould in the form of compacts. The composition of the substrates of the reaction of the TiC synthesis was next enriched with an Fe filler added in an amount of 10 and $50 \mathrm{wt}$. \% to investigate the possibility of changing the hardness of the composite zone. The addition of filler changed the surface fraction and the average size of TiC precipitates. In the case of the 50 wt. \% addition, a tenfold reduction in the dimensions of the carbides was obtained. This increased their surface fraction relative to the compact composition containing only $10 \mathrm{wt}$. \% of the filler. Changes in mechanical properties were analysed within the zone area by the measurement of hardness HV. The study showed a gradual decrease of the zone hardness in function of the amount of the filler added. This trend was also true as regards the composite zone in castings, where a significant refinement and increased surface content of the TiC precipitates was observed.
\end{abstract}

Keywords: MMCs, in situ, composites zone, TiC, castings

W pracy omówiono metodę wytwarzania stref kompozytowych w odlewach z ferrytyczno-perlitycznego żeliwa sferoidalnego. Fazą wzmacniającą strefy kompozytowej był węglik tytanu (TiC), uzyskany w wyniku syntezy in situ substratów wprowadzonych do formy w postaci wyprasek. Do kompozycji substratów reakcji syntezy TiC wprowadzono wypełniacz, proszek Fe w ilości 10 i $50 \%$ mas. w celu zbadania możliwości zmiany twardości strefy kompozytowej. Dodatek wypełniacza spowodował zmianę udziału powierzchniowego oraz średniej wielkości TiC. W przypadku $50 \%$ mas. dodatku wypełniacza otrzymano dziesięciokrotne zmniejszenie wymiarów węglików. Analizowano zmiany mechaniczne w obrębie strefy, badając jej twardość HV. Badana wykazały stopniowy spadek twardości strefy wraz z ilością dodawanego wypełniacza. Tendencja ta dotyczyła również strefy kompozytowej odlewu, w którym stwierdzono znaczne rozdrobnienie wydzieleń TiC i wzrost ich udziału powierzchniowego.

\section{Introduction}

Two basic processes that cause the destruction of cast structural components are the abrasive wear and corrosion. To prevent the former, parts of the machinery, equipment and vehicles are made from the abrasion-resistant alloys. In many cases, for these applications, the alloys are selected that can offer the highest hardness values. Unfortunately, for most structures, especially those working in extractive, cement, bitumen and construction industries, this choice often proves to be quite unsuccessful. This is due to the working conditions of the components, which during operation are subjected to high impact loads. In castings made of extra hard alloys and usually having poor impact resistance, the consequence is the formation of cracks and ultimately fatal damage of the component. The solution that allows preventing such problems is the use of castings in which the working surface is resistant to wear, while core can carry the dynamic loads [1].

One of the solutions is in the very promising laser technologies, which enable precise remelting of the casting surface with the simultaneous introduction of hard ceramic phases [2,3]. Laser technologies can indeed increase surface hardness, but their applicability in remelting the layers of a substantial thickness is quite unrealistic. Like welding, hardfacing can lead to cracking of castings due to the formation of large temperature gradients. Of great importance is here the heat-affected zone, which can destroy the structure of the base alloy, resulting in e.g. the dissolution of carbides thermodynamically unstable.

Another very interesting and promising technology is pouring of foundry mould with two alloys, each of different properties [4,5]. Typically, one of these alloys is characterised by high impact strength and another by high hardness.

In recent years, the development of composite technology has been observed to take place in the industry. In this group of materials, an important place is occupied by the ex-situ composites [6-11], in which the reinforcing phase is introduced into the liquid alloy, or another material, by stirring. Another variation are composites of in-situ type, in which the reinforcing phase can be formed as a result of the spontaneous 
exothermic chemical reaction in the metal bath [12-18]. The composite manufacturing is a single-step process. This method allows, in addition to the production of the reinforcing phase within the total alloy volume, also local reinforcement of the selected casting area [19-21].

The paper presents the technology of the in-situ manufacture of composite zones at the casting edge based on the ferritic-pearlitic ductile iron. To better investigate the possibility of undisturbed shaping of mechanical properties within the composite zone, an Fe filler was introduced to the substrates of the $\mathrm{TiC}$ reaction of synthesis. Then its effect on the process of synthesis, on structural changes within the zone area and on the base alloy microstructure outside the zone area was studied. The average surface fraction of carbides and the average size of $\mathrm{TiC}$ carbide crystals within the obtained zones were determined for different compositions. Finally, hardness $\mathrm{HV}$ of the obtained zones was analysed.

\section{Experimental}

A mixture of substrates necessary for the titanium carbide synthesis was prepared in the atomic ratio of $1: 1$, according to reaction 1 :

$$
T i+C=T i C
$$

For this purpose, commercial products such as titanium powder (purity $99.98 \%$, average size $44 \mu \mathrm{m}$ ) and graphite pow$\operatorname{der}(99.99 \%, 44 \mu \mathrm{m})$ were used. The prepared powders were stirred under argon protective atmospheare for 24 hours, and then three compositions of substrates necessary for the synthesis of composite zones in castings were made. One of them contained only a stoichiometric mixture of titanium and carbon, while the second and the third composition had an addition of filler in order to investigate the possibility of changing the hardness of the composite zone in the from of iron powder $(99.4 \%, 44 \mu \mathrm{m})$. The weight, volume fraction of substrates used for the synthesis, filler added to compacts of different composition and porosity of compacts are given in Table 1.

TABLE 1

The weight, volume fraction of components and porosity of compacts used in the process of the composite zone manufacture

\begin{tabular}{|c|c|c|c|c|c|c|}
\hline \hline $\begin{array}{c}\text { Casting } \\
\text { symbol }\end{array}$ & $\begin{array}{c}\text { Weight } \\
\text { fraction } \\
\text { of filler } \\
\text { [wt. \%] }\end{array}$ & $\begin{array}{c}\text { Weight } \\
\text { fraction } \\
\text { of } \\
\text { substrate } \\
\text { for TiC } \\
\text { synthesis } \\
\text { [wt. \%] }\end{array}$ & $\begin{array}{c}\text { Volume } \\
\text { fraction } \\
\text { Ti } \\
\text { [vol. \%] }\end{array}$ & $\begin{array}{c}\text { Volume } \\
\text { fraction } \\
\text { C } \\
\text { [vol. \%] }\end{array}$ & $\begin{array}{c}\text { Volume } \\
\text { fraction } \\
\text { Fe } \\
\text { [vol. \%] }\end{array}$ & $\begin{array}{c}\text { Poro- } \\
\text { sity } \\
\text { of } \\
\text { com- } \\
\text { pacts } \\
\%\end{array}$ \\
\hline $\begin{array}{c}\text { base } \\
\text { alloy }\end{array}$ & - & - & - & - & - & - \\
\hline M50 & 50 & 50 & 45.2 & 22.5 & 32.3 & 19 \\
\hline M90 & 10 & 90 & 63.4 & 31.6 & 5 & 14 \\
\hline M100 & 0 & 100 & 66.8 & 33.2 & 0 & 7 \\
\hline
\end{tabular}

The powder mixtures weighing $0.03 \mathrm{~kg}$, shown in Table 1 , were compressed under a pressure of $500 \mathrm{MPa}$. The dimensions of compacts without filler and with the addition of filler in an amount of 10 and 50 wt. $\%$ were $10 \times 15 \times 50$, $10 \times 14.5 \times 50$ and $10 \times 12 \times 50 \mathrm{~mm}^{3}$, respectively.
Y shaped ingot $(25 \mathrm{~mm})$ were made of bentonite moulding sand. Then, on the bottom of each of them, the previously prepared compacts were placed and the whole was dried at $373 \mathrm{~K}$ for $1 \mathrm{~h}$. In the one mould four compacts with one composition was placed. Scheme of the mould with the compacts shows in Figure 1. In one mould, four compacts of the same composition were placed. A scheme of the mould with compacts inside is shown in Figure 1.

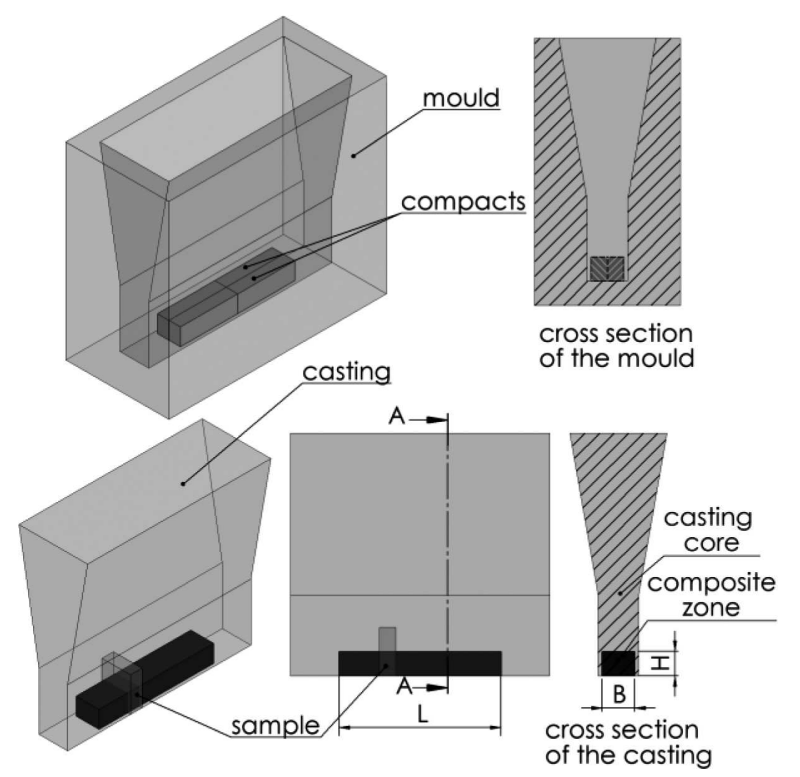

Fig. 1. Scheme of mould with compacts inside and of casting with the composite zone and marked place of sampling

Melting of the base alloy was carried out in an induction furnace of the IMSK-10 type (Inductal Gelingen, Germany). The obtained ingots shaped in Y were cut, ground, polished and deep-etched for metallographic examinations and testing of mechanical properties. Etching was carried out with aqua regia and with the $\mathrm{HCl}$ to $\mathrm{HNO}_{3}$ ratio of $3: 1$.

The structure of the composite zones obtained in castings and of the base alloy was examined using a Kristalloflex $4 \mathrm{~h}$ $\mathrm{X}$-ray diffractometer (Siemens, Germany) and $\mathrm{CuK} \alpha \mathrm{X}$-rays of $0,1548 \mathrm{~nm}$ wavelength. The examinations were carried out at a voltage of $30 \mathrm{kV}$ and a current of $20 \mathrm{~mA}$.

Imaging of microstructure in thus obtained materials was carried out by electron microscopy, using a SU-70 (Hitachi, Japan) scanning electron microscope. Backscattered electrons mode (BSE) and secondary electrons (SE) were used. The average diameter of the carbide precipitates and their surface fraction were determined using ImageJ programme.

Hardness HV of the tested materials was measured using an HPO 250 hardness tester under a load of $294.2 \mathrm{~N}$ and a loading time of 15 seconds.

The, shown in Table 1, powder mixtures weighing $\sim 0.03 \mathrm{~kg}$ were compressed under a pressure of $500 \mathrm{MPa}$.

\section{Results}

Figure 2 shows images of macrostructures of the composite zones produced in castings M100, M90 and M50. All produced zones are located in the lower part of castings. Their width $B$ and the length L (Fig. 1) are $\sim 23 \mathrm{~mm}$ and $\sim 100 \mathrm{~mm}$, 
respectively. The zone height $\mathrm{H}$ (Fig. 1), measured in the middle part of the metallographic section shown in Figure 2, are 15, 15 and $16 \mathrm{~mm}$ for castings M100, M90 and M50, respectively. The zones produced in castings are characterised by two-layer structure. The first layer of non-uniform structure occupies about one-third of the surface area and is located within the casting edge. The second layer, located above the first one, has a uniform macrostructure and occupies the remaining surface area of the composite zone produced.

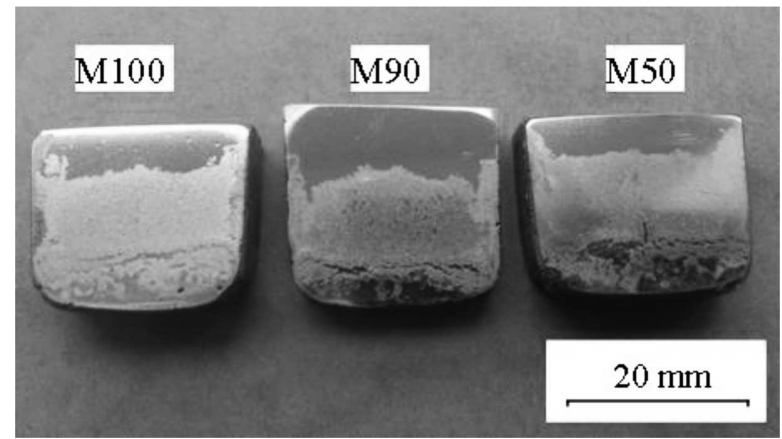

Fig. 2. Photo of macrostructures of composite zones produced in castings M100, M90 and M50

Figure $3 \mathrm{a}$ shows the results of X-ray diffraction on the planes of the structures occurring within the composite zones obtained in castings made of alloys M100, M90 and M50, and of the base alloy. The Bragg reflections 110, 220, 211 and 310 visible in all diffraction patterns are derived from the structure of iron $\alpha(\mathrm{Fe} \alpha)$ classified in the space group 229 with the abbreviated symbol Im-3m. Other reflections visible on the diffraction patterns of alloys containing composite zones,

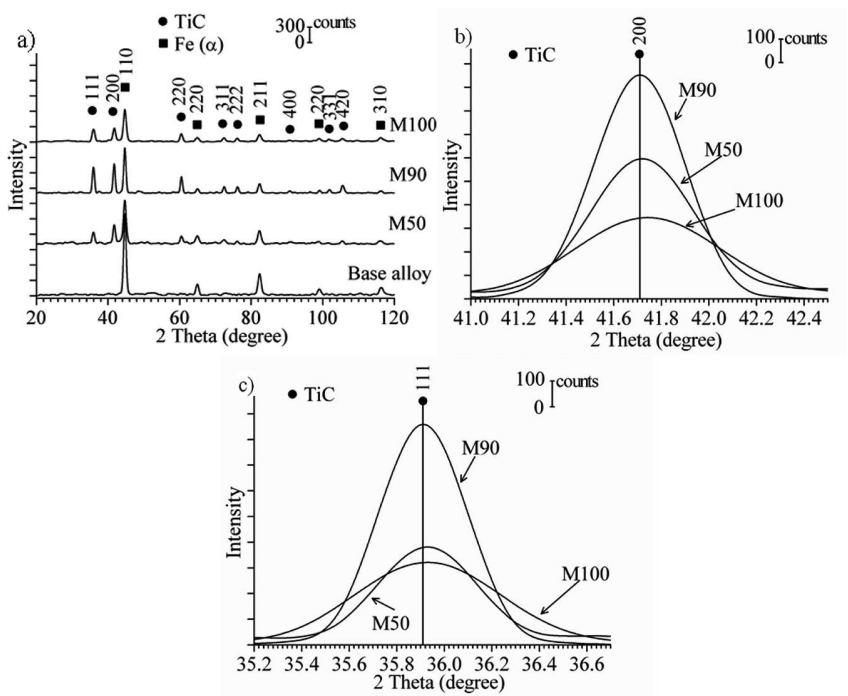

Fig. 3. Phase analysis of composite zones produced in alloys M100, M90 and M50 and in base alloy

i.e. alloys M100, M90 and M50, are derived from the structure of titanium carbide with the space group number 225 and the symbol Fm-3m. The Bragg reflections shown in Figure $3 b-c$ originating from the planes (111) and (100) of the TiC carbide structure show no shifts relative to the pattern. The $\mathrm{TiC}$ carbide lattice parameter has remained unchanged in all composite zones produced in the examined castings. Bragg reflections from the planes of graphite $\left(\mathrm{C}_{g r}\right)$ and cementite $\left(\mathrm{Fe}_{3} \mathrm{C}\right)$ are not present in all the diffraction patterns obtained. The volume fraction of these phases in the base alloy and in the composite zones is small. Therefore, their detection in the present case was not possible.

Figure 4 shows the SE image of the microstructure of the base alloy, which is ferritic-pearlitic ductile iron. In this Figure one can see the precipitates of nodular graphite (black), visible against the background of ferrite (dark grey) surrounded by pearlite (light grey).

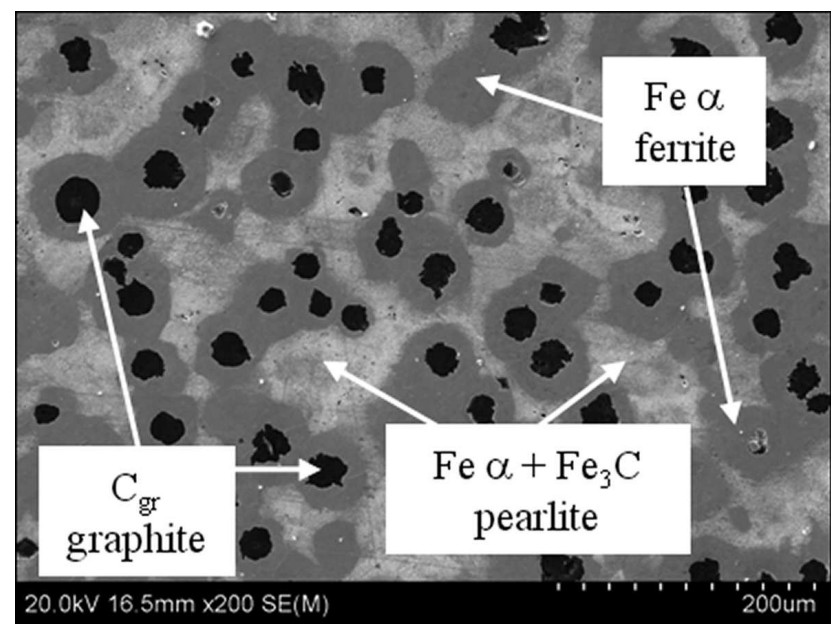

Fig. 4. SE image of the microstructure of the base alloy, which is ductile iron with a ferritic-pearlitic matrix

Figure 5 shows the BSE images of the microstructure in the transition regions between the composite zone and the core of castings M100 (Fig. 5a), M90 (Fig. 5b) and M50 (Fig. 5c). In Figure 5 a-c one can see the titanium carbides obtained by the in-situ synthesis in matrix (grey) and graphite precipitates (black). The transition area between the casting core and the composite zone is free from the cracks and discontinuities. In all composite zones graphite is observed, however their surface fraction decreases with content of carbides. Also the shape of graphite was changed in composite area with surface fraction of the carbides and filler.

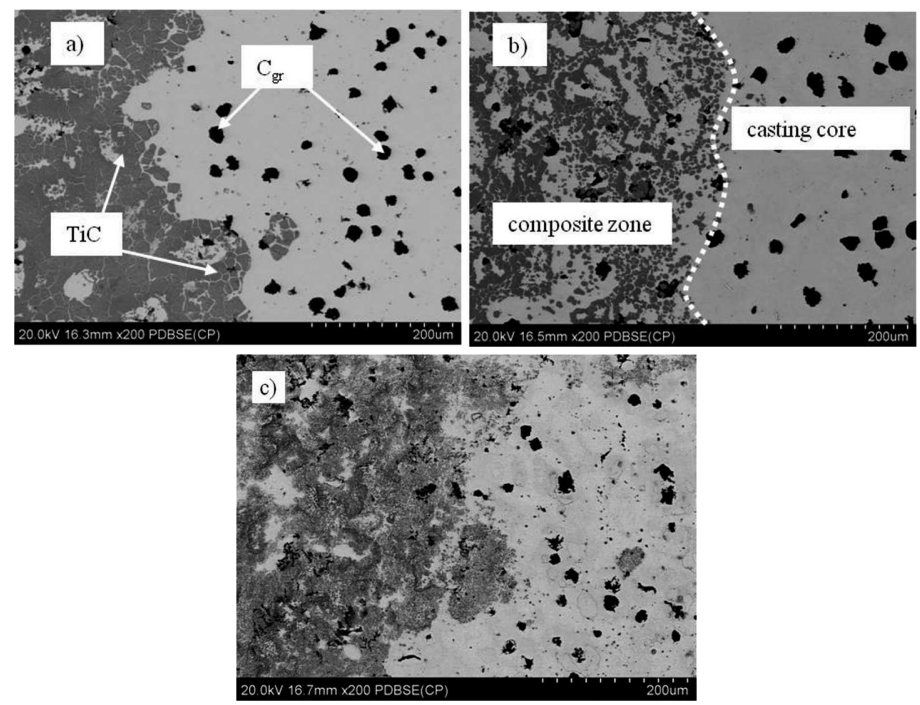

Fig. 5. BSE images of microstructures obtained in a transition region between the composite zone and the casting core in castings M100 (a), M90 (b) and M50 (c) 
Figure 6 shows the BSE images of the microstructure produced in the composite zone of casting M100. Within this zone (Fig. 6a) one can see numerous clusters of carbides, forming conglomerates and coagulated forms of the size reaching even $\sim 100 \mu \mathrm{m}$. Between these areas, in the matrix, freely distributed, scarce, non-faceted carbides, oval and dendritic in shape, appear (Fig. 6b). The zone produced in casting M100 has a cellular structure similar to that observed in foams [22-25]. The irregular closed cells [24,25] are composed of conglomerated and coagulated carbides. Free spaces between $\mathrm{TiC}$ and the interior of cells are filled with the matrix, which consists of the base alloy phases, including $\alpha \mathrm{Fe}, \mathrm{Fe}_{3} \mathrm{C}$ and $\mathrm{C}_{g r}$. In the microstructure of the zone produced in casting M100, the cell walls and cell edges, characteristic of the cellular structure, can be distinguished (Fig. 6a). Within the zone area, a tendency of the edges of cells to become enriched with TiC is observed. Figure $6 \mathrm{c}$ shows the image of a deep-etched microstructure in the zone of casting M100 with a well visible closed cell.
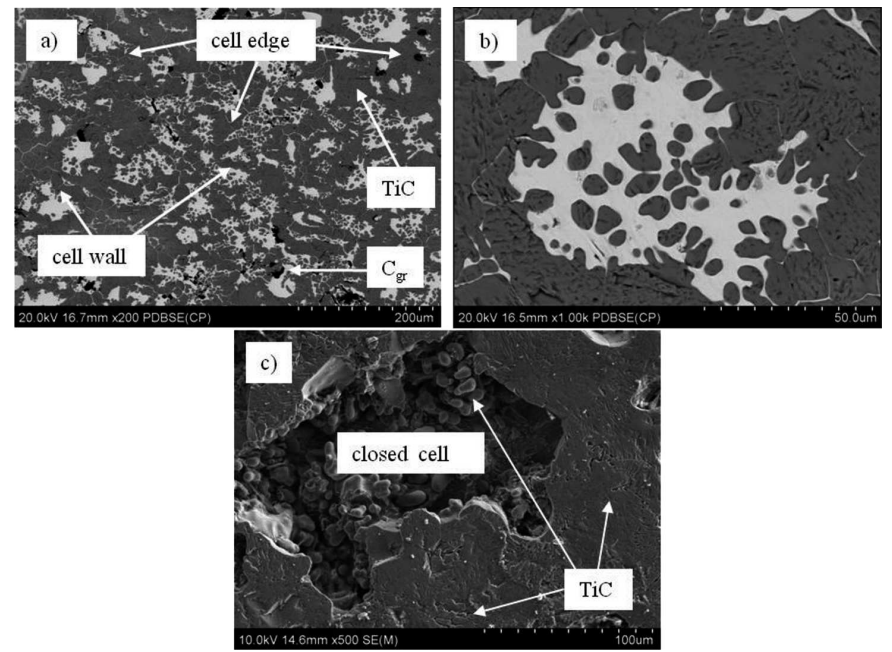

Fig. 6. BSE images of the composite zone (a-b) and SE image of the closed cell morphology after deep etching (c) obtained in casting M100

Like the composite zone in casting M100, also the, in-situ obtained, composite zone in casting M90 (Fig. 7) is characterised by a large number of the conglomerated TiC carbides of a non-uniform distribution. The carbides visible in Figure 7 form irregular, closed rings, inside which the alloy matrix shows. Compared with the composite zone in casting M100 (Fig. 6), the number of carbides freely surrounded by the matrix has obviously increased. A smaller number of the coagulated phases is also visible. Microstructure of the composite zone in casting M90 has a cellular form, created by numerous carbides which are in contact with each other. The closed cells are of an irregular, often elongated, shape. Compared with the composite zone in casting M100, the surface of the cell edges and of the cell walls is smaller in the composite zone of casting M90. This results in a noticeable increase in the surface of the cells filled with the matrix. The cellular structure of the composite zone in casting M90 is well illustrated in Figures $7 \mathrm{c}$ and $7 \mathrm{~d}$. The deep-etched matrix reveals the closed-cell morphology, consisting of many interconnected TiC carbides.
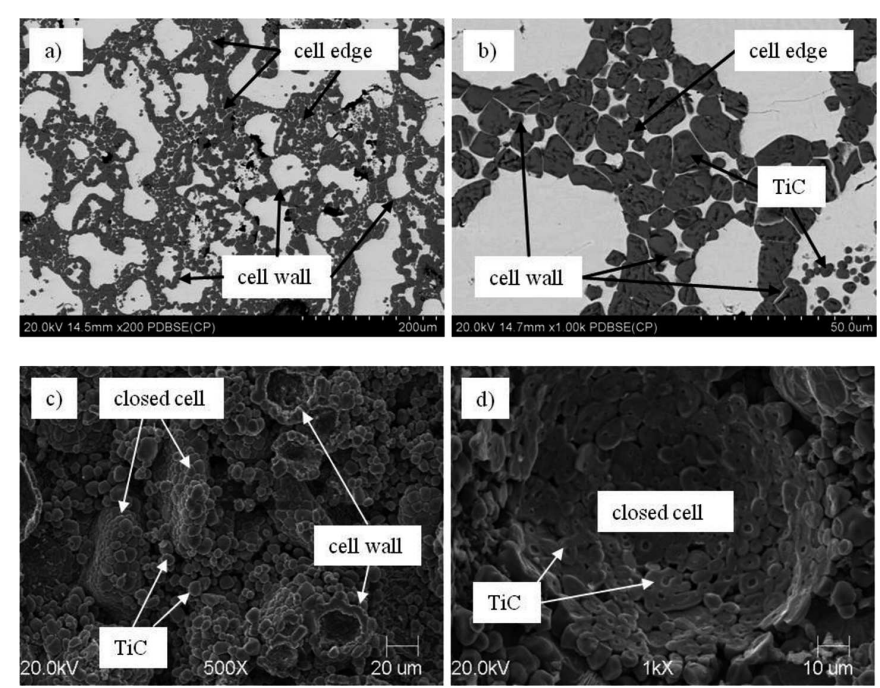

Fig. 7. BSE images of the composite zone (a-b) and SE images of the closed cell morphology after deep etching (c-d) obtained in casting M90

Figure 8 shows the microstructure of a composite zone produced in casting M50. The composite zone in this casting is characterised by a high degree of the refinement of the precipitates of the reinforcing phase (Figs. $8 \mathrm{a}$ and $8 \mathrm{~b}$ ). The titanium carbides are uniformly distributed within the matrix and do not form, as in previous cases (Figs. 6 and 7), the coagulated phases (Fig. 8c) The conglomerates are only very scarce in occurrence.

Figure 8d shows the image of a deep-etched microstructure in the zone of casting M50 with a well visible TiC carbides.
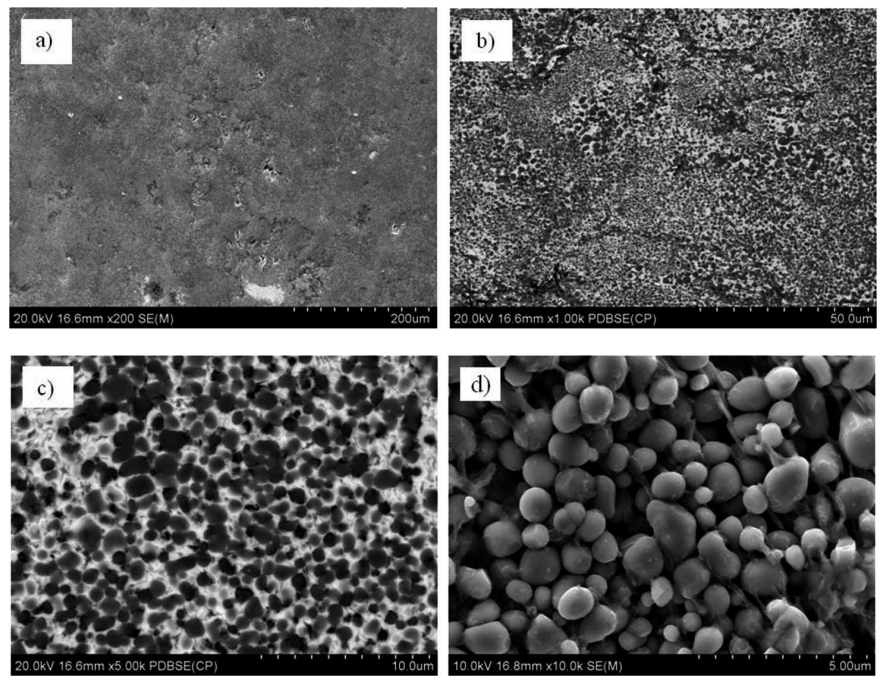

Fig. 8. BSE images of the composite zone obtained in casting M50 (a-c) and SE images of the morphology TiC after deep etching (d)

The results of measurements of the surface fraction of carbides within the composite zones obtained in castings M50, M90 and M100 are shown in Figure 9. The collective results indicate that the highest surface content of $\mathrm{TiC}$ carbides was obtained in the composite zone of casting M100, and it amounted to $72.4 \pm 3.8 \%$. However, these results are burdened with large measurement uncertainty resulting from heterogeneous distribution of the reinforcing phase in matrix. In the case of casting M90, the average surface fraction is maintained 
at a level of $46.9 \pm 1.8 \%$. A very surprising result was obtained, when the content of $\mathrm{TiC}$ was examined in the composite zone of casting M50, produced with a compact containing 50 wt.\% of the filler. The average surface fraction of carbides in this zone was $59.8 \% \pm 1.8$.

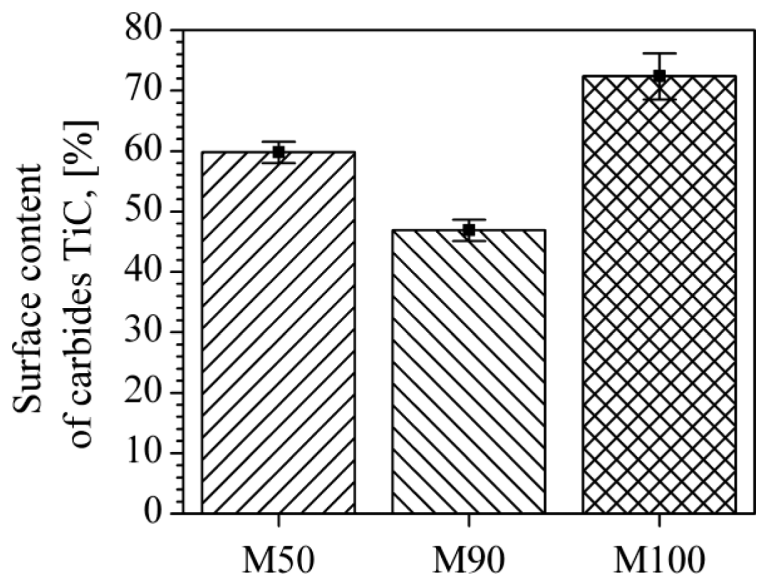

Fig. 9. Surface fraction of carbides in the composite zone of castings M50, M90 and M100

The average size of $\mathrm{TiC}$ carbides in the composite zone of castings M90 and M50 is shown in Figure 10. The data presented in the graph indicate that the size of the carbide precipitates has decreased with the increasing content of filler added to the compact. The composite zone obtained in casting M50 contains carbide precipitates of extremely small dimensions, i.e. at an average level of $\sim 0.88 \mu \mathrm{m}$. This means nearly 10 fold reduction in the dimensions of the precipitates relative to the composite zone in alloy M90. The comparison does not include the size of carbides obtained in the composite zone of casting M100, mainly because of their highly coagulated and conglomerated form.

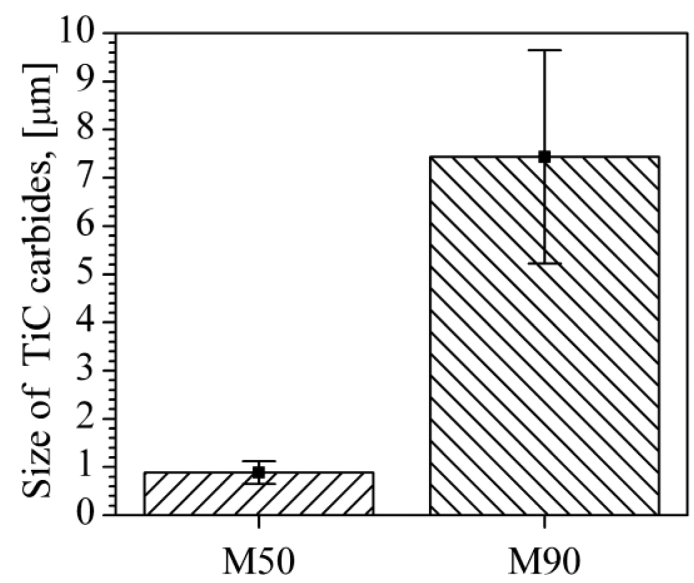

Fig. 10. The results of the measurements of the size of TiC carbides produced in the composite zone of castings M90 and M50

Figure 11 illustrates the results of the hardness measurements obtained for the base alloy and for the composite zone in castings M100, M90 and M50. The average hardness values obtained in the composite zone of alloys M100, M90, M50 and in the base alloy amount to $742 \pm 163 \mathrm{HV}, 562 \pm 29 \mathrm{HV}$, $256 \pm 38 \mathrm{HV}$ and $207 \pm 10 \mathrm{HV}$, respectively. In alloy M100, compared to the base alloy, an average threefold increase in the hardness of the composite zone was obtained, though in areas with the highest concentration of the reinforcing phase it reached a level up to five times higher. At the same time, the measurement of hardness in the composite zone of casting M100 was characterised by the largest scatter of results, mainly due to a high degree of heterogeneity observed in the examined area.

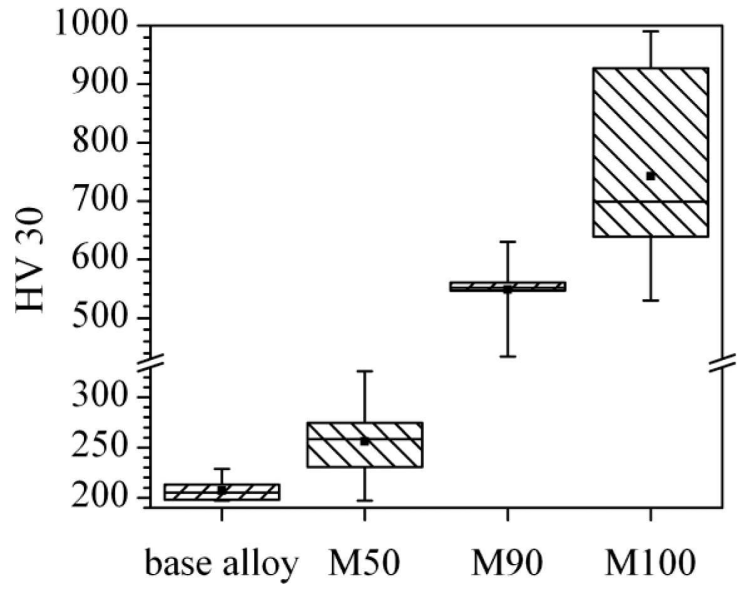

Fig. 11. The results of the measurements of hardness HV in casting made of the base alloy and in the composite zone of castings M100, M90 and M50

\section{Discussion}

Introducing into moulds the compacts containing substrates for the titanium carbides reaction of synthesis enables obtaining composite zones in castings based on the ferritic-pearlitic ductile iron. The synthesis of TiC occurs at the moment when molten alloy is poured into the mould. The heat supplied to the compact by molten alloy initiates in this compact the reaction of synthesis, which ultimately leads to the formation of TiC [14-15]. Similar results of in-situ synthesis in the liquid alloy the authors have already obtained in other materials [1]. However, in previous studies, no filler has been applied. Its role is to reduce the carbides content in the zone. A control of this parameter enables unrestrained development of the mechanical properties in the casting composite zone and, consequently, in the entire cast structural component.

The conducted research using filler in the form of $\mathrm{Fe}$ powder showed the possibility of $\mathrm{TiC}$ synthesis in compacts containing even up to $50 \mathrm{wt}$. \% of this filler. Its presence might adversely affect the process of the synthesis as such. The temperature $T_{p}$ at which the liquid alloy was poured into a mould is $1723 \mathrm{~K}$, while the melting point $T_{m}$ of pure iron used as a filler is $1811 \mathrm{~K}$. So, the melting point of iron powder was by $88 \mathrm{~K}$ higher than $T_{p}$ and therefore the melting and dissolution of iron powder took place as a consequence of heat supplied by the highly exothermic reaction of the TiC carbide synthesis [13]. As a consequence, there has been a total conversion of substrate in the presence of Fe. The X-ray diffraction analysis (Fig. 3) showed that the TiC carbide lattice parameters remained unchanged in all the examined composite zones. This indicates lack of the apparent dissolution of $\mathrm{Ti}$ in the matrix.

The imaging of microstructure in the produced composite zones allowed studying their morphology. In the case of 
the zone in casting M100, the $\mathrm{TiC}$ carbides obtained in the synthesis were very coagulated and conglomerated (Fig. 5). The addition of filler in an amount of $10 \mathrm{wt} \%$ has improved the carbides distribution. In the composite zone of casting M90 these carbides were less coagulated, and the number of carbides freely distributed in the matrix increased (Fig. 6). Composite zones in castings M100 and M90 have a cellular structure. In both cases, these are closed cells, composed of numerous TiC carbides. In the zone of casting M100, carbides forming walls and edges of the cells are highly conglomerated and coagulated. On the other hand, in the composite zone of casting M90, within the walls and edges of the cells, the microstructure of a core-rim type, observed in cermets, appears $[26,27]$. In the case under discussion, the core made of $\mathrm{TiC}$ is surrounded by a rim of the matrix. The walls and edges of the cells in the zone of casting M100 have a much larger surface area than in the zone of casting M90. This significantly affects the decrease in the average cell surface area in casting M100. In the case of the composite zone in casting M90, an increase in the cell surface area is visible with reduced thickness of the cell walls and of the surface area of their edges. A large surface area of the cell walls and edges in the zone of casting M100 is mainly related with the composition and pressure applied to compacts. Compacts used to produce a composite zone in casting M100 contained only a stoichiometric mixture of Ti and $\mathrm{C}$ powders, compacted under a pressure of $500 \mathrm{MPa}$. The consequence of this fact is a low content of the matrix, due to poor penetration of the liquid alloy during in situ reaction of the $\mathrm{TiC}$ synthesis. In the case of the zone obtained in casting M90, where compacts were produced with $10 \mathrm{wt} \%$ filler, the surface area of the cell walls and edges is visibly reduced. Here, filler plays the role of a diluent for the obtained in situ carbides. As a result, a growth of the cell surface area is observed.

The best results were obtained with the filler addition to a compact at a level of $50 \mathrm{wt} . \%$. The composite zone in casting M50 was characterised by a very uniform distribution of strongly refined carbides (Fig. 8). The filler introduced to the compacts considerably improved the carbides morphology, particularly as regards the number of carbides freely distributed in the matrix. Along with an increase of this parameter, the impact strength improved, and the crack formation tendency in the composite zone was reduced.

Surface analysis (Fig. 9) showed an unpredictable increase in the content of TiC carbides in the composite zone of casting M50. It has considerably exceeded the surface fraction of carbides in the composite zone of casting M90.

The increased surface fraction of carbides obtained in the composite zone of casting M50 is related with an average size of the TiC carbide precipitates produced in this casting (Fig. 8). It was found that the size of $\mathrm{TiC}$ carbides in the composite zone of casting M50 was ten times smaller than in the case of casting M90 (Fig. 10). So significant reduction in the size of TiC crystals increased their surface content in the matrix.

The conducted mechanical tests have shown that the highest increase in hardness HV (threefold in relation to the matrix) was obtained in the composite zone of casting M100 (Fig. 11). This results from a large surface fraction of carbides and their coagulated and conglomerated forms (Fig. 6), affecting the stiffness of the zone. With filler added, the hardness of the composite zones decreases. Despite an increase in the surface fraction of $\mathrm{TiC}$ in the composite zone of casting M50 (Fig. 9), the hardness was not observed to increase (Fig. 11). This effect is due to the fact that the TiC carbides in casting M50 are freely distributed in a soft ferritic-pearlitic matrix (Fig. 8). Since the composite zone in this casting has practically no conglomerated or coagulated forms, it loses its rigidity. The indenter of a hardness tester easily penetrates the composite zone material.

\section{Conclusions}

The in-situ synthesis of TiC carbides takes place in the mould causing virtually no changes in the phase composition of the base alloy. The use of a filler in the form of iron powder reduces the size of $\mathrm{TiC}$ carbides, resulting in a substantial increase of their surface content. The filler introduced into the compact reduces hardness of the composite zone, allowing a smooth transition of the properties. Iron powder added to the composition of the substrates of the $\mathrm{TiC}$ reaction of synthesis in a very clear manner reduces the dimensions of the carbides.

Adding $50 \mathrm{wt} . \%$ of the filler to a compact reduces hardness of the composite zone, but other mechanical properties of this zone are quite interesting. The authors of this study anticipate further investigations carried out in this respect.

In long term, it would also be interesting to investigate the effect of higher filler content on the size of carbide precipitates. It is believed that an increase in its content might produce zones with the precipitates of nanometric dimensions. Taking into account the dimensions of the composite zone produced in castings, the synthesis of nano-composite by a method as simple as this one would be very attractive.

\section{Acknowledgements}

The research formed a part of the study No. N N507 311040 financed by the Polish Ministry of Science and Higher Education.

\section{REFERENCES}

[1] P. Mierzwa, E. Ole jnik, A. J a nas, Archives of Foundry Engineering 12, 137 (2012).

[2] H. Pa r k, K. N a k a t a, S. To m i d o, Journal of Materials Science 35, 747 (2000).

[3] M. Rozmus-Górnikowska, J. Kusiński, M. B li chars ki, Archives of Metallurgy and Materials 56 (3), 717 (2011).

[4] J. S u choń, Archives of Foundry Engineering 10, 214 (2003).

[5] J. S u cho ń, Archives of Foundry Engineering 22, 483 (2006).

[6] J. M y a $1 \mathrm{~s} \mathrm{ki}$, Engineering Science 6, 745 (2002).

[7] J. M y a $1 \mathrm{~s} \mathrm{ki,} \mathrm{J.} \mathrm{Ś} 1$ e z i o n a, Journal of Materials Processing Technology 175, 291 (2006).

[8] A. Dolat a-Grosz, B. Formane k, J. Ślezion a, J. W i e c z or e k, Journal of Materials Processing Technology 162-163, 33 (2005).

[9] A. Zyska, J. B r a s z c z yńs ki, Z. Kon opka, Kompozyty (Composites) 1, 114 (2001).

[10] J. Le li t o, P. Ż a k, J.Sz. S u c h y, Archives of Metallurgy and Materials 54 (2), 347 (2009). 
[11] M. Pot o c z e k, R.E. Ś 1 iw a, Archives of Metallurgy and Materials 56 (4), 1265 (2011).

[12] Z.A. Munir, U. A n s e $1 \mathrm{~m}$ i - T a m burin i, Metallurgical Transactions B 19, 155 (1988).

[13] A.G. M e r z h a n ov, Journal of Materials Processing Technology 56, 222 (1996).

[14] E. F r a ś, A. J a n a s, A. Ko 1 b u s, M. Gó r n y, Archives of Metallurgy 44 (3), 253 (1999).

[15] E. Fraś, A. J a n a s, P. Kurtyka, S. W i e r z b i ń s ki, Archives of Metallurgy and Materials 48, 383 (2003).

[16] E. Frás, A. J a n a s, A. Kolbu s, E. O le jn i k, Archives of Foundry Engineering 6 (18), 317 (2006).

[17] A. Jan as, A. Kolbus, E. Ole jnik, Archives of Metallurgy and Materials 54 (2), 319 (2009).

[18] L. Zh on g, Y. X u, X. Li u, F. Ye, Journal of Materia Science 46, 2814 (2011).

[19] K. A s a no, H. Yoneda, Materials Transactions 49 (10), 2394 (2008).
[20] E. Olejnik, A. J a n a s, A. Kolbus, B. Grabow ska, Composites Theory and Practice 11 (2), 120 (2011).

[21] E. Olejnik, A. J an as, G. Sikora, T. Tokarski, J. N o w a k, Archives of Foundry Engineering 13 (1), 107 (2013).

[22] E. A n d rew s, W. S a n d e r s, L.J. Gi b s o n, Materials Science and Engineering A 270, 113 (1999).

[23] S.F. E d w a r d s, K.D. P i th i a, Physica A 215, 270 (1995).

[24] C. P a r k, S.R. N u t t, Materials Science and Engineering A 299, 68 (2001).

[25] Z.G. X u, J.W. F u, T.J. L u o, Y.S. Y a n g, Materials Design 34, 40 (2012).

[26] J. K i m, M. S e o, S. K a n g, Materials Science and Engineering A 528, 2517 (2011).

[27] H. K w o n, S. K a n g, Materials Science and Engineering A 520, 75 (2009). 